Article

\title{
Production, Preparation and Characterization of Microalgae-Based Biopolymer as a Potential Bioactive Film
}

\author{
Mónica Morales-Jiménez ${ }^{1,2}$, Luisa Gouveia ${ }^{3, *} \mathbb{C}^{\mathbb{C}}$, Jorge Yáñez-Fernández ${ }^{2} \mathbb{D}$, \\ Roberto Castro-Muñoz ${ }^{4}$ (D) and Blanca Estela Barragán-Huerta ${ }^{1, *(\mathbb{D})}$ \\ 1 Escuela Nacional de Ciencias Biológicas, Instituto Politécnico Nacional, Avenida Wilfrido Massieu s/n, \\ Unidad Profesional Adolfo López Mateos, Mexico City 07738, Mexico; mmoralesj1902@alumno.ipn.mx \\ 2 Unidad Profesional Interdisciplinaria de Biotecnología, Instituto Politécnico Nacional, Avenida Acueducto \\ s/n, Barrio la Laguna Ticomán, Mexico City 07340, Mexico; jyanez68@hotmail.com \\ 3 Laboratório Nacional de Energia e Geologia (LNEG), Unidade de Bioenergia, Estrada do Paço do Lumiar 22, \\ 1649-038 Lisboa, Portugal \\ 4 Tecnologico de Monterrey, Campus Toluca, Avenida Eduardo Monroy Cárdenas 2000, \\ San Antonio Buenavista, Toluca de Lerdo 50110, Mexico; food.biotechnology88@gmail.com \\ * Correspondence: luisa.gouveia@lneg.pt (L.G.); bbarraganh@ipn.mx (B.E.B.-H.)
}

Received: 18 December 2019; Accepted: 28 January 2020; Published: 31 January 2020

check for updates

\begin{abstract}
Six microalgae strains were screened according to their biomass productivity and polymer synthesis, showing biomass productivity between 0.14 and $0.68 \mathrm{~g} /(\mathrm{L} \cdot \mathrm{d})$ for a 21-day growth period. Extracellular biopolymers from the spent culture media of Nostoc sp. (No), Synechocystis sp. (Sy), and Porphyridium purpureum ( $\mathrm{Pp}$ ) was obtained, and the yields of the clean biopolymer were 323, 204, and $83 \mathrm{mg} / \mathrm{L}$, respectively. The crude biopolymer was cleaned up using a solid-phase extraction technique. The emulsification index $\mathrm{E}_{24}$ values for the clean biopolymer were $77.5 \%, 68.8 \%$, and $73.3 \%$ at $0.323,0.083$, and $0.204 \mathrm{mg} / \mathrm{mL}$, respectively. The clean biopolymer of the No strain showed the highest fungal growth inhibition against Fusarium verticillioides (70.2\%) and Fusarium sp. (61.4\%) at $2.24 \mathrm{mg} / \mathrm{mL}$. In general, transparent and flexible biofilms were prepared using biopolymers of No and Pp. The microstructural analysis revealed the presence of pores and cracks in the biofilms, and the average roughness Ra values are 68.6 and $86.4 \mathrm{~nm}$ for No and Pp, respectively, and the root mean square roughness $\mathrm{Rq}$ values are 86.2 and $107.2 \mathrm{~nm}$ for No and Pp, respectively.
\end{abstract}

Keywords: microalgae; biopolymer; emulsification; antifungal; biofilms

\section{Introduction}

Nowadays, most packaging materials are still derived from nonrenewable sources. These synthetic polymers have been used as packaging materials for many years due to their economic and technological advantages, such as high availability, low cost, and favorable functional properties. However, such polymers present hydrophobic nature, which limits the action of microorganisms, and therefore takes many years to decompose. This results in the production of large volumes of solid wastes, which leads to serious environmental problems. These issues have been greatly aggravated due to the increase in population and economic growth from developed and developing countries. Hence, the need to reduce the amount of discarded plastics is being recognized globally, aiming to replace them with packaging films based on biodegradable materials, which are recognized as environmentally friendly materials [1].

Food, as the largest packaging user, and packaging industries have been joining efforts to reduce amounts of nonbiodegradable food packaging materials, since environmental issues are the major 
concern of consumers. Therefore, several studies are being carried out, involving the development of new materials to produce packaging for short-term biodegradation. It is likely that the future generation of packaging materials will be derived from renewable and biodegradable resources [2].

Packaging plays a very important role in food preservation and in health-enhancing foods [3]. Food packages usually act as inert barriers for product protection with no interaction with food. However, edible films can provide additional protection for food, while being a fully biodegradable and environmentally friendly packaging system. Biofilms, as the primary barrier against physical impacts, prevent contamination, increase shelf life and contain important information about packaged food. In addition, biofilms can be used to improve food quality, as they can carry functional ingredients such as fatty acids, antioxidants, antimicrobials, nutrients, and flavors to further enhance food quality, stability, functionality, and safety [4].

The most common materials used in the formulation of edible films are proteins (e.g., gelatin, casein, wheat gluten, and zein) and polysaccharides (e.g., alginate, starch, and chitosan), which are used alone or blended. These biopolymers are highly biodegradable and decompose easily into inorganic by-products like carbon dioxide and water [5]. The use of vegetable raw materials to produce biodegradable packaging is then a favorable alternative.

Some species of microalgae (e.g., Spirulina sp., Isochrysis galbana, Nannochloropsis oculata, Synechocystis sp. (Sy), and Nostoc sp. (No)) can produce functional compounds with high added value, including essential fatty acids, pigments, proteins, polysaccharides, vitamins, and minerals. Due to the presence of biologically active compounds with antioxidant, antitumoral, anti-inflammatory, neuroprotective, and coloring properties in its biomass, microalgae are already being marketed as food supplements/additives (e.g., omega 3 and omega 6 fatty acids and pigments). In addition, microalgae are also being used to increase the nutritional content of conventional foods [6-10]. On the other hand, microalgae-based polymers have not yet been tested regarding the production of bioactive films and emulsification properties. Thereby, in this work, six microalgae strains (Porphyridium purpureum (Pp), No, Spirulina maxima (Sm), Sy, Scenedesmus obliquus (So), and Spirogyra sp. (Sp)) were screened to evaluate their potential for biopolymer production. Three of the biopolymers were selected, due to their extracellular biopolymer production; the antifungal and antibacterial activities as well as the emulsifying capacities and the antioxidant effects of the biopolymers were also evaluated.

\section{Materials and Methods}

\subsection{Chemicals}

The reagents used in this study were all of analytical grade, i.e., Albumin fraction V (Merck, Darmstadt, Germany), D-glucose anhydrous (Pronalab, Lisbon, Portugal), Trolox (97\% 6-hydroxy2,5,7,8-tetramethylchroman-2-carboxylic acid) and ABTS (2, 2'-azino-bis-(3-ethylbenzothiazoline 6-sulfonic acid) diammonium salt) (Sigma-Aldrich, Toluca, Mexico).

\subsection{Biological Materials}

The strains of Pp SAG 1380-1a, No, Sm, Sy PCC 6803, So, and Sp SAG 170.80 were provided by the Laboratório Nacional de Energia e Geologia, Lisbon, Portugal. Escherichia coli ATCC 43895, Xanthomona campestris ATCC 13951, and the phytopathogenic fungi-Botrytis cinerea NRRL 1650, Colletotrichum gloeosporioides, Curvularia sp., Fusarium sp., Fusarium verticillioides, and Helminthosporium sp.- -were obtained from Escuela Nacional de Ciencias Biológicas, Instituto Politécnico Nacional, Mexico City, Mexico.

\subsection{Microalgae Culture}

$\mathrm{Pp}, \mathrm{No}, \mathrm{Sm}, \mathrm{Sy}, \mathrm{So}$, and Sp were cultivated in an autotrophic culture medium [11-13], using airlift bioreactors (capacity: 1L) with bubbling air at $1 \mathrm{vvm}$, a constant temperature of $25 \pm 1{ }^{\circ} \mathrm{C}$, 
and continuous white light illumination $\left(100 \mu \mathrm{E} /\left(\mathrm{m}^{2} \cdot \mathrm{s}\right)\right)$ from fluorescence lamps (Philips TL-D 18W/54-765, Lisbon, Portugal.

A $10 \mathrm{~mL}$ sample of the culture was taken each 3 days to evaluate the growth rate by the optical density at $540 \mathrm{~nm}$ using a Hitachi U-2000 spectrophotometer. The $\mathrm{pH}$ of the medium was measured using a $\mathrm{pH}$ meter (INOLAB, WTW, Weilheim, Germany). The dry biomass productivity was evaluated every 7 days. Culture samples of 3.0-10.0 mL were taken and filtered through a GF/C filter with a $1.2 \mu \mathrm{m}$ pore size and dried at a constant temperature of $80^{\circ} \mathrm{C}$, and the dry biomass concentration was calculated. The biomass productivity was expressed as dry biomass in grams per liter per day $(\mathrm{g} /(\mathrm{L} \cdot \mathrm{d}))$.

After 21 days (at stationary phase), the agitation of the culture was stopped, and the culture was later centrifuged at 12,000 rpm for $10 \mathrm{~min}$ in order to harvest the biomass and separate the crude extracellular medium.

\subsection{Polymer Precipitation Capacity}

Typically, microalgae-based polymers are extracted from biomass, and the culture medium was discarded. However, in this research, the presence of polymer was tested by selective precipitation from both the microalgae biomass extract and the crude extracellular medium. In the first scenario, one gram of the fresh microalgae biomass was suspended in $100 \mathrm{~mL}$ of $0.05 \% \mathrm{NaCl}$ and heated at $80^{\circ} \mathrm{C}$ for $10 \mathrm{~min}$ with constant magnetic stirring. Then, the extract was filtered to vacuum with a Whatman filter, $11 \mu \mathrm{m}$ pore size. In the second scenario, the crude extracellular medium did not have additional treatment. The microalgae biomass extract and the crude extracellular medium were analyzed in terms of sugar and protein contents to obtain the biopolymer by precipitation.

For the precipitation test, a $10 \mathrm{~mL}$ sample of the microalgae biomass extract and the crude extracellular medium was mixed with $10 \mathrm{~mL}$ of a $0.5 \%$ aqueous cetrimide solution. The precipitate obtained was dialyzed (dialysis tubing cellulose membrane, typical molecular weight cut-off $=14,000$ ) against $1 \mathrm{~L}$ of distilled water for a two-day period with daily water bath change. After dialysis, the precipitate obtained was used for biofilm preparation.

\subsection{Film-Forming Capacity}

From the previous step, the crude extracellular medium and extract, which generated a precipitate, were used to produce biofilms using a sample of $0.3 \mathrm{~g}$ of the polymer precipitate. Due to scarcely available information concerning biofilm production from microalgae, five combinations were tested considering two solvents, two plasticizers, four preparation ways, and two drying strategies, resulting in the following formulations:

- The fresh polymer precipitate was dissolved in $10 \mathrm{~mL}$ of $5 \% \mathrm{NaCl}$ with gentle agitation on a hot plate, until the temperature reached $60^{\circ} \mathrm{C}$. The plasticizer $(1.0 \mathrm{~mL}$ of glycerol) was added, and the agitation continued for two more minutes. Then, the viscous solution was precipitated with $0.5 \%$ cetrimide in a ratio of $1: 1(v / v)$. The precipitate was recovered, laminated and dried at $25^{\circ} \mathrm{C}$ for $24 \mathrm{~h}$.

- The fresh polymer precipitate was dissolved in $10 \mathrm{~mL}$ of $5 \% \mathrm{NaCl}$ with gentle agitation on a hot plate, until the temperature reached $60^{\circ} \mathrm{C}$. The plasticizer $(0.5 \mathrm{~g}$ of D-sorbitol) was added, and the agitation continued for two more minutes. Then, the viscous solution was precipitated with $0.5 \%$ cetrimide in a ratio of $1: 1(v / v)$. The precipitated was recuperated, laminated and dried at $25^{\circ} \mathrm{C}$ for $24 \mathrm{~h}$.

- The fresh polymer precipitate was dissolved in $10 \mathrm{~mL}$ of $5 \% \mathrm{NaCl}$ with gentle agitation on a hot plate, until the temperature reached $60^{\circ} \mathrm{C}$. The plasticizer $(1.0 \mathrm{~mL}$ of glycerol) was added, and the agitation continued for two more minutes. The viscous solution obtained was poured in a petri dish and dried at $30^{\circ} \mathrm{C}$ for $12 \mathrm{~h}$.

- The fresh polymer precipitate was dissolved in $20 \mathrm{~mL}$ of $0.1 \mathrm{M} \mathrm{NaOH}$ with gentle agitation on a hot plate, until the temperature reached $80^{\circ} \mathrm{C}$. The plasticizer $(1.0 \mathrm{~mL}$ of glycerol) was added, 
and the agitation continued for $20 \mathrm{~min}$. The viscous solution was emptied in a petri dish and dried at $30^{\circ} \mathrm{C}$ for $12 \mathrm{~h}$.

- The fresh polymer precipitate was dissolved in $20 \mathrm{~mL}$ of $0.1 \mathrm{M} \mathrm{NaOH}$ with gentle agitation on a hot plate, until the temperature reached $80^{\circ} \mathrm{C}$. The plasticizer $(1.0 \mathrm{~mL}$ of glycerol $)$ was added, and the agitation continued for $20 \mathrm{~min}$. The viscous solution obtained was precipitated with $0.5 \%$ cetrimide in a ratio of $1: 1(v / v)$. The precipitated was later recuperated, laminated and dried at $25^{\circ} \mathrm{C}$ for $24 \mathrm{~h}$.

\subsection{Microstructure Analysis of the Biofilms}

\subsubsection{SEM}

The surface microstructure was analyzed by SEM, and five surface images of the biofilms were obtained using Quanta ${ }^{\mathrm{TM}}$ 3D 250 FEG Scanning Electron Microscope (Thermo Fisher Scientific Inc., Eugene, OR, USA) at $30 \mathrm{kV}$ and an environmental resolution.

\subsubsection{Atomic Force Microscopy (AFM)}

Samples of squares films (area: $1.0 \mathrm{~cm}^{2}$ ) were analyzed in a Veeco Atomic Force Microscope (Multimode V NanoScope, New York, NY, USA) connected to a controller (diNanoScope V, New York, NY, USA). Five areas of the film's surface $(15 \mu \mathrm{m} \times 15 \mu \mathrm{m})$ were scanned using probes (RTEST) in the tapping mode at a scan rate of $1 \mathrm{~Hz}$ [14]. The roughness parameters, average roughness (Ra), and root mean square roughness (Rq) were obtained using NanoScope Analysis v7.30 software (Veeco, New York, NY, USA). The 3D images were observed in NanoScope Analysis v1.40 software (Veeco, New York, NY, USA).

\subsection{Bioactivity of Microalgae Polymers}

\subsubsection{Biopolymer Clean-up}

A clean-up process for the crude extracellular medium by solid phase extraction using C18 cartridges was implemented to obtain a clean biopolymer. In this step, hydrophobic compounds produced during algal growth cycles were eliminated.

Fifty milliliters of samples from the dialyzed extracellular medium were passed through a previously conditioned C18 column (ISOLUTE ${ }^{\mathrm{TM}} \mathrm{C} 18,500 \mathrm{mg}, 6 \mathrm{~mL}$, Biotage, Charlotte, NC, USA). The nonretained fraction in the column, which corresponded to the clean extracellular medium, was collected and roto-evaporated to dryness at $40^{\circ} \mathrm{C}$. The yield of the cleaned and dried biopolymer was expressed as mg per liter of extracellular medium.

\subsubsection{Antifungal Activity}

All fungi strains used were activated on natural potato dextrose agar (PDA) prepared according to Sun et al. [15], using $0.37 \mathrm{mg} / \mathrm{mL}$ lincomycin and $0.37 \mathrm{mg} / \mathrm{mL}$ chloramphenicol to minimize contamination with bacteria. For inhibition assays, a $0.5 \mathrm{~cm}$ cylindrical portion of agar was removed from the center of the plate to create a cavity. An aliquot of $200 \mu \mathrm{L}$ clean biopolymer with a concentration of $2.24 \mathrm{mg} / \mathrm{mL}$ dissolved in $3 \% \mathrm{NaCl}$ was placed into the cavity. The plates were incubated at $28^{\circ} \mathrm{C}$ for $24 \mathrm{~h}$ to allow for the diffusion of samples in the agar. Subsequently, the plates were inoculated with a $0.5 \mathrm{~cm}$ mycelium plug and incubated at $28{ }^{\circ} \mathrm{C}$ for 5 days. A negative control $(3 \% \mathrm{NaCl})$ and a positive control (2.0 mg/mL fluconazole) were carried out simultaneously. All trials were performed in duplicate. The radial growth was measured, and the inhibition percentage was calculated using Equation (1):

$$
\begin{gathered}
\text { Inhibition }(\%)=\frac{\text { negative control area }- \text { treatment area }}{\text { negative control area }} \times 100 \%, \\
\text { area }=\pi \cdot \mathrm{r}^{2} .
\end{gathered}
$$




\subsubsection{Antibacterial Activity}

Escherichia coli was activated in a liquid medium, Muller Hilton Broth, and then incubated at $35{ }^{\circ} \mathrm{C}$ for $24 \mathrm{~h}$. Xanthomonas campestris was grown in plates using the yeast extract dextrose calcium carbonate agar and incubated at $28^{\circ} \mathrm{C}$ for $24 \mathrm{~h}$. The Escherichia coli inoculum was prepared according to Sadat et al. [16] through a dilution with a $0.85 \% \mathrm{NaCl}$ sterile solution, until it reached turbidity equal to a $0.5 \mathrm{McF}$ arland standard, which approximately corresponds to $10^{8} \mathrm{CFU} / \mathrm{mL}$. The Xanthomonas campestris inoculum was prepared through a dilution with a $0.85 \% \mathrm{NaCl}$ sterile solution, until it reached an absorbance of 0.5 at $600 \mathrm{~nm}$, which approximately corresponds to $10^{8} \mathrm{CFU} / \mathrm{mL}$ [17]. Antibacterial activity was evaluated using the agar diffusion technique, where a $5 \mu \mathrm{L}$ inoculum was placed into the agar and expanded with a bacteriological loop. Then, a $0.7 \mathrm{~cm}$ sterile metallic cylinder was introduced into the agar, and a $25 \mu \mathrm{L}$ aliquot of the $2.24 \mathrm{mg} / \mathrm{mL}$ clean biopolymer dissolved in $3 \% \mathrm{NaCl}$ was tipped, before the cylinder was quickly removed; aliquots of $25 \mu \mathrm{L}$ of $3 \% \mathrm{NaCl}$ and $2.0 \mathrm{mg} / \mathrm{mL}$ lincomycin were used as negative and positive controls, respectively. The plates, in duplicate, were incubated at $28^{\circ} \mathrm{C}$ for $24 \mathrm{~h}$. The inhibition zone was measured and reported in centimeters.

\subsubsection{Antioxidant Activity}

The antioxidant activity of the clean biopolymer was determined by antiradical capacity using the ABTS radical technique [18]. Trolox dissolved in ethanol was used for the calibration curve. Seven milliliters of aqueous ABTS was mixed with $2.45 \mathrm{mM}$ potassium persulfate and incubated for $16 \mathrm{~h}$ in the dark to generate free radicals. ABTS radical was diluted with ethanol to achieve an absorbance of $0.7 \pm 0.05$ at $734 \mathrm{~nm}$. A $100 \mu \mathrm{L}$ aliquot of the sample was added to $1.9 \mathrm{~mL}$ of diluted ABTS radical, vortexed for $10 \mathrm{~s}$ and kept in the dark for $7 \mathrm{~min}$. The absorbance was measured at $734 \mathrm{~nm}$, using as $100 \mu \mathrm{L}$ blank $3 \% \mathrm{NaCl}$, and similarly reacted with $1.9 \mathrm{~mL}$ ABTS radical. The samples of $2 \mathrm{mg} / \mathrm{mL}$ clean biopolymer dissolved in $3 \% \mathrm{NaCl}$ were tested in triplicate.

\subsection{Emulsification Index Test of the Extracellular Medium}

Both the crude and clean extracellular media were tested to determine their emulsification indices at $24 \mathrm{~h}\left(\mathrm{E}_{24}\right)$ using kerosene as a hydrocarbon. $\mathrm{E}_{24}$ was determined by mixing $2 \mathrm{~mL}$ of kerosene and $2 \mathrm{~mL}$ of the sample in a $15 \mathrm{~mL}$ Falcon screw-capped tube. The tube was stirred during two minutes using a vortex, and the mixture was allowed to stand for $24 \mathrm{~h}$. $\mathrm{E}_{24}$ was calculated by dividing the height of the emulsion layer by the mixture total height and then multiplying by 100 [19]. The samples were tested in triplicate.

\subsection{Protein and Sugar Analysis}

Lowry's method was used for protein analysis [20]. Bovine albumin serum was used as a standard for the calibration curve, and the absorbance was measured at $750 \mathrm{~nm}$. The phenol-sulfuric acid method was used for the sugar analysis [21]. D-glucose was used as a standard for the calibration curve, and the absorbance was measured at $485 \mathrm{~nm}$. Samples of $1.0 \mathrm{~mL}$ of the microalgae biomass extract and $1.0 \mathrm{~mL}$ of the crude extracellular medium were analyzed in triplicate. The results were expressed as $\mathrm{mg}$ D-glucose/g fresh biomass and $\mathrm{mg}$ protein/g fresh biomass for microalgae biomass extract and were expressed as $\mathrm{mg}$ D-glucose/L and $\mathrm{mg}$ protein/L for the crude extracellular medium.

\subsection{FT-IR Analysis of the Clean Biopolymers}

Five milligrams of the clean biopolymer powder was mixed with $50 \mathrm{mg}$ potassium bromide powder, the mixture was compressed into a pellet, and its IR spectrum at wavenumbers from 500 to $4000 \mathrm{~cm}^{-1}$ was recorded using a Spectrum 2000 FTIR spectrometer (Perkin Elmer, Inc., Waltham, MA, USA). 


\subsection{Statistical Analysis}

Results from independent assays are reported as the mean \pm standard deviation. Means were compared by ANOVA and the Tukey's comparison test, with a significance level $p<0.05$. Data were processed and analyzed in Minitab 17 (Minitab Inc., State College, PA, USA).

\section{Results and Discussion}

\subsection{Microalgal Growth and Biomass Productivity}

The strain with the fastest growth was Sm (Figure 1), with a maximum productivity of $0.68 \mathrm{~g} /(\mathrm{L} \cdot \mathrm{d})^{-1}$, which was more than three times higher than the value reported by Barrocal et al. [22], $0.20 \mathrm{~g} /(\mathrm{L} \cdot \mathrm{d})^{-1}$. The study was performed in autotrophic conditions for 21 days under light-dark cycles of 16 and $8 \mathrm{~h}$ separately. In addition, the productivity values obtained for the strains, So, Sp, and Pp, were similar $\left(0.33-0.41 \mathrm{~g} /(\mathrm{L} \cdot \mathrm{d})^{-1}\right)$; however, the microalga No showed a decay in the last measurement. The use of microalgal biomass has been focused on obtaining high-value products as well as biofuels. Importantly, algae products and their high-value compounds (e.g., amino acids, carbohydrates, minerals, trace elements, phytohormones, sterols, and organic compounds and oils) are currently considered as alternatives to biofertilizers, biostimulants, [7,23], bioplastics [24-26], and liquid fossil fuels [27], among others.

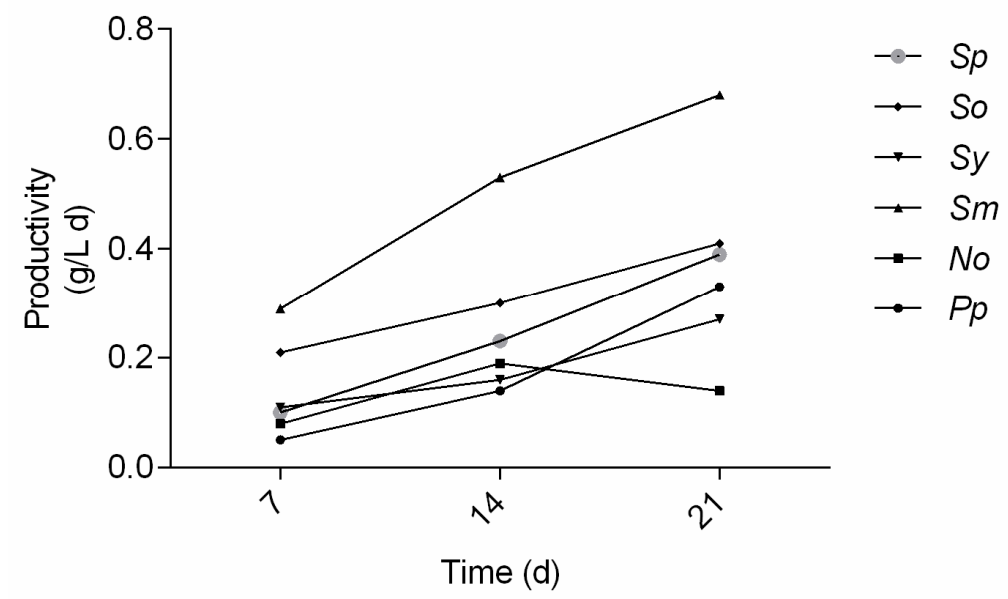

Figure 1. Productivity $\left(\mathrm{g} /(\mathrm{L} \cdot \mathrm{d})^{-1}\right)$. Pp: Porphyridium purpureum; No: Nostoc sp.; Sm: Spirulina maxima; Sy: Synechocystis sp.; So: Scenedesmus obliquus, Sp: Spirogyra sp.

\subsection{Polymer Precipitation Capacity}

Before the polymer precipitation test, sugar and protein contents were evaluated in the microalgae biomass extract and the crude extracellular medium. In general, the microalgae biomass extract presented sugar contents between $2.6 \pm 0.0$ and $10.3 \pm 0.1 \mathrm{mg} / \mathrm{g}$ fresh biomass and protein contents between $9.5 \pm 0.0$ and $31.8 \pm 1.3 \mathrm{mg} / \mathrm{g}$ fresh biomass, where So and No had the highest sugar and protein contents, respectively (Table 1 ). 
Table 1. Sugar and protein contents in the microalgae biomass extract and the crude extracellular medium.

\begin{tabular}{|c|c|c|c|c|}
\hline \multirow{2}{*}{ Microalgae } & \multicolumn{2}{|c|}{ Microalgae Biomass Extract } & \multicolumn{2}{|c|}{ Crude Extracellular Medium } \\
\hline & Sugar ${ }^{(1)^{*}}$ & Protein ${ }^{(2)^{*}}$ & Sugar ${ }^{(3)^{*}}$ & Protein ${ }^{(4)^{*}}$ \\
\hline $\mathrm{Pp}$ & $9.6 \pm 0.1^{b}$ & $9.5 \pm 0.0^{\mathrm{c}}$ & $0.09 \pm 0.0^{\mathrm{a}}$ & $0.03 \pm 0.0^{\mathrm{d}}$ \\
\hline No & $8.6 \pm 0.1^{\mathrm{c}}$ & $31.8 \pm 1.3^{\mathrm{a}}$ & $0.03 \pm 0.0^{\mathrm{c}}$ & $0.10 \pm 0.0^{\mathrm{c}}$ \\
\hline Sm & $2.6 \pm 0.0^{f}$ & $16.8 \pm 0.2^{b}$ & $0.02 \pm 0.0^{\mathrm{d}}$ & $0.34 \pm 0.0^{\mathrm{a}}$ \\
\hline Sy & $7.4 \pm 0.1^{\mathrm{d}}$ & Not detected & $0.04 \pm 0.0^{b}$ & $0.15 \pm 0.0^{b}$ \\
\hline So & $10.3 \pm 0.1^{\mathrm{a}}$ & Not detected & $0.02 \pm 0.0^{\mathrm{d}}$ & Not detected \\
\hline $\mathrm{Sp}$ & $5.0 \pm 0.0^{\mathrm{e}}$ & Not detected & $0.05 \pm 0.0^{b}$ & Not detected \\
\hline
\end{tabular}

Pp: Porphyridium purpureum; No: Nostoc sp.; Sm: Spirulina maxima; Sy: Synechocystis sp.; So: Scenedesmus obliquus; Sp: Spirogyra sp. ${ }^{(1)} \mathrm{mg}$ D-glucose/g fresh biomass; ${ }^{(2)} \mathrm{mg}$ protein/g fresh biomass; ${ }^{(3)} \mathrm{mg}$ D-glucose/L; ${ }^{(4)} \mathrm{mg}$ protein/L. Data are shown as mean $\pm S D(n=3) .{ }^{*}$ Means with different letters are significantly different according to ANOVA and the Tukey test (comparison between strains) $(p<0.05)$.

For the crude extracellular medium, the sugar content was in the range from $0.02 \pm 0.0$ to $0.09 \pm 0.0 \mathrm{mg} / \mathrm{L}$ of the medium, and the protein content was from $0.03 \pm 0.0$ to $0.34 \pm 0.0 \mathrm{mg} / \mathrm{L}$ of the medium. Pp showed the highest extracellular sugar content, and Sm presented the highest extracellular protein content (Table 1). These results are relevant, due to the limited information related to the exploitation of extracellular biopolymers from microalgae.

Although the microalgae biomass extracts contain sugar and protein, none of them were positive to the precipitation test. In contrast, the polymers precipitations from the crude extracellular media of $\mathrm{Pp}, \mathrm{No}$, and Sy were successful. Henceforth, these three strains in the culture medium were selected for the next studies.

According to Gloaguen et al. [28], an extracellular polysaccharide of Porphyridium sp. as a complex was precipitated due to ionic interaction. In addition, Andhare et al. [29] found that the precipitation method with quaternary ammonium salts at a concentration of $2 \%$ showed the minimum structural abrasion and a high efficiency during the precipitation of an exopolysaccharide (succinoglycan) from Rhizobium radiobacter. None of them demonstrated the production of biofilms from the biopolymer.

\subsection{Film-Forming Capacity}

The precipitates from the crude extracellular media of $\mathrm{Pp}$ and No were able to form a film according to the proposed methods. Table 2 enlists the proposed formulations, as well as the preparation procedures. For instance, formulation I for both strains (Table 2) was selected as the best process conditions to obtain films (Figure 2). 
Table 2. Characteristics of the biofilms of precipitates obtained from the crude extracellular medium.

\begin{tabular}{|c|c|c|c|c|c|}
\hline \multirow{2}{*}{ Formulation } & \multirow{2}{*}{$\begin{array}{c}\text { Solvent/ } \\
\text { Plasticizer }\end{array}$} & \multirow{2}{*}{ Preparation/Drying } & \multicolumn{3}{|c|}{ Biofilm Characteristics } \\
\hline & & & No & $\mathbf{P p}$ & Sy \\
\hline I & $\begin{array}{c}5 \% \\
\mathrm{NaCl} / \text { Glycerol }\end{array}$ & $\begin{array}{l}\text { Agitation at } 60^{\circ} \mathrm{C} \text { for } 2 \mathrm{~min} \\
\text { precipitation and lamination } \\
\text { at } 25^{\circ} \mathrm{C} \text { for } 24 \mathrm{~h}\end{array}$ & $\begin{array}{l}\text { Thin, } \\
\text { transparent and } \\
\text { flexible. }\end{array}$ & $\begin{array}{l}\text { Thin, } \\
\text { transparent and } \\
\text { with mobility. }\end{array}$ & $\begin{array}{l}\text { Does not form } \\
\text { film }\end{array}$ \\
\hline II & $\begin{array}{c}5 \% \\
\mathrm{NaCl} / \mathrm{D}-\text {-sorbitol }\end{array}$ & $\begin{array}{l}\text { Agitation at } 60^{\circ} \mathrm{C} \text { for } 2 \mathrm{~min}, \\
\text { precipitation and lamination } \\
\text { at } 25^{\circ} \mathrm{C} \text { for } 24 \mathrm{~h}\end{array}$ & Fragile & $\begin{array}{l}\text { Thin, } \\
\text { transparent and } \\
\text { with mobility. }\end{array}$ & $\begin{array}{l}\text { Does not form } \\
\text { film }\end{array}$ \\
\hline III & $\begin{array}{c}5 \% \\
\mathrm{NaCl} / \text { Glycerol }\end{array}$ & $\begin{array}{c}\text { Agitation at } 60^{\circ} \mathrm{C} \text { for } 2 \mathrm{~min} \\
\text { and emptying in petri dish } \\
\text { at } 30^{\circ} \mathrm{C} \text { for } 12 \mathrm{~h}\end{array}$ & $\begin{array}{l}\text { Does not form } \\
\text { film }\end{array}$ & $\begin{array}{l}\text { Does not form } \\
\text { film }\end{array}$ & $\begin{array}{l}\text { Does not form } \\
\text { film }\end{array}$ \\
\hline IV & $\begin{array}{c}0.1 \mathrm{M} \\
\mathrm{NaOH} / \mathrm{Glycerol}\end{array}$ & $\begin{array}{c}\text { Agitation at } 80^{\circ} \mathrm{C} \text { for } 20 \mathrm{~min} \\
\text { and emptying in petri dish } \\
\text { at } 30^{\circ} \mathrm{C} \text { for } 12 \mathrm{~h}\end{array}$ & $\begin{array}{l}\text { Does not form } \\
\text { film }\end{array}$ & $\begin{array}{l}\text { Does not form } \\
\text { film }\end{array}$ & $\begin{array}{l}\text { Does not form } \\
\text { film }\end{array}$ \\
\hline V & $\begin{array}{c}0.1 \mathrm{M} \\
\mathrm{NaOH} / \mathrm{Glycerol}\end{array}$ & $\begin{array}{l}\text { Agitation at } 80^{\circ} \mathrm{C} \text { for } 20 \mathrm{~min} \\
\text { and precipitation and } \\
\text { lamination at } 25^{\circ} \mathrm{C} \text { for } 24 \mathrm{~h}\end{array}$ & $\begin{array}{l}\text { Thin, } \\
\text { transparent, } \\
\text { rough and } \\
\text { flexible }\end{array}$ & $\begin{array}{l}\text { Gross, rough } \\
\text { and fragile }\end{array}$ & $\begin{array}{l}\text { Does not form } \\
\text { film }\end{array}$ \\
\hline
\end{tabular}

No: Nostoc sp.; Pp: Porphyridium purpureum; Sy: Synechocystis sp.

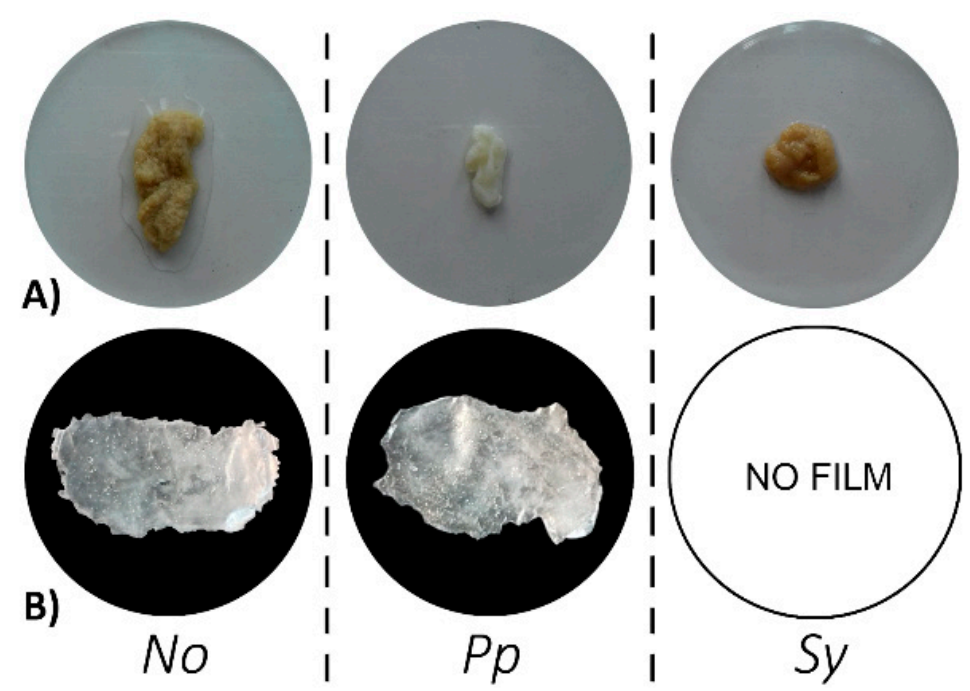

Figure 2. Precipitates (A) and biofilms from formulation $I^{*}$ (B). No: Nostoc sp.; Pp: Porphyridium purpureum; Sy: Synechocystis sp. ${ }^{*}$ Conditions: fresh polymer precipitate dissolved in $5 \% \mathrm{NaCl}$, and were mixed with glycerol as a plasticizer and dried at $25^{\circ} \mathrm{C}$ for $24 \mathrm{~h}$.

To the best of our knowledge, this is the first report about the isolation of polymers with the capacity to produce a transparent and flexible film from the exhausted microalgae in the culture medium. These qualitative characteristics are more promising in the field of packaging materials than those found by Benelhadj et al. [30], who reported the production of a fragile film with a dark brown color using a protein extracted from Arthrospira (Spirulina) platensis biomass. On the other hand, transparent biofilms are also useful in wound dressings due to the allowance of a better monitoring of the healing process [31].

The method proposed in this work involves the possibility to look for another quaternary ammonium salt in the film production, in order to obtain a similar potential application to that recently achieved by Demirci et al. [32]. Their research was focused on adding quaternary ammonium salts to a polymeric matrix of polyurethane, with the objective of allowing for the antimicrobial activity of the polymer, which is an application of wider utility.

By analyzing the morphological properties of the polymeric matrix, the SEM images of the surface (Figure 3A) showed cracks, fibrillary appearance, and presence of pores in the biofilm from No. The surface image of the biofilm from Pp was darker, and PP showed a smoother appearance 
than No; nevertheless, it presented bigger and deeper pores. Bierhalz et al. [33] in their study with alginate-chitosan membranes (films) exhibited that the porosity allowed for the permeability of gases and water vapor, a favorable characteristic for its application in coverages of skin wounds through cell therapy. It is essential to mention that biopolymers (such as chitosan, sodium alginate, cellulose-based polymers, polylactic acid, and polyhydroxyalkanoates) are currently used as potential membrane materials in several technologies, such as microfiltration, ultrafiltration, pervaporation, gas separation, and membranes for tissue engineering [34,35]. In fact, the authors have mentioned the importance of getting nonanimal-origin biopolymers for biomaterial and tissue engineering fields [33]. The principal differences between the biofilm surfaces from No and Pp might be due to the type of network biopolymer formed, and although the laminate technique was the same, it could interfere in the structural conformation. Definitely, the film preparation procedure will play an important role in the physical properties of final polymer films [36].

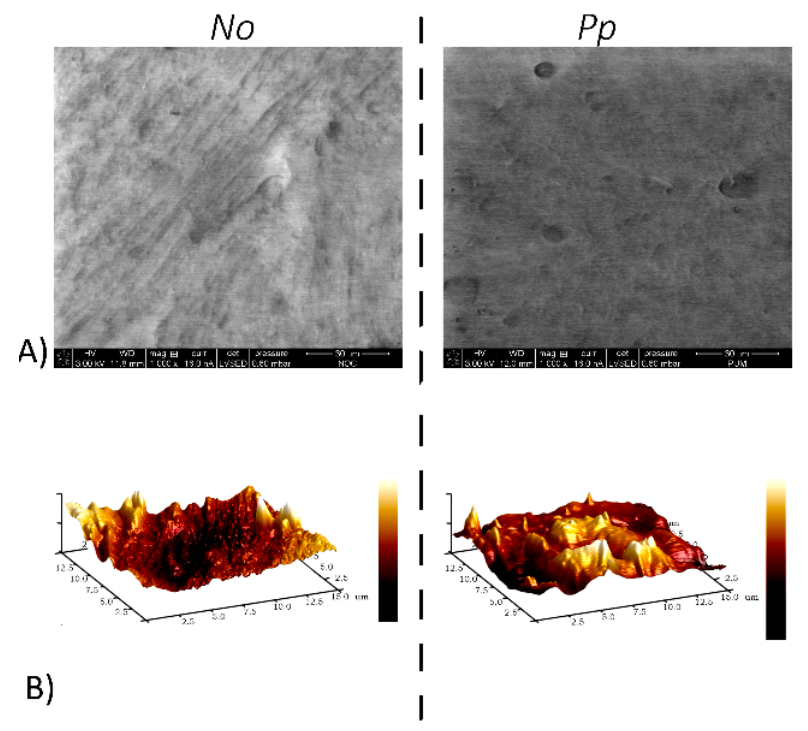

Figure 3. SEM (A)* and atomic force microscopy $(\mathbf{B})^{*}$ images of the biofilms. No: Nostoc sp.; Pp: Porphyridium purpureum. ${ }^{*}$ indicates a selected image. $\mathrm{n}=5$.

The AFM topographic images (Figure 3B) of the biofilms showed irregular appearance, with agglomerates and high parameters roughness. No presented an average roughness value of $\mathrm{Ra}=68.6 \mathrm{~nm}$ and a root mean square roughness value of $\mathrm{Rq}=86.2 \mathrm{~nm}$; for $\mathrm{Pp}$, the values were shown as following: $\mathrm{Ra}=86.4 \mathrm{~nm}$ and $\mathrm{Rq}=107.2 \mathrm{~nm}$. Higher roughness values imply greater contact surfaces, which could act as a carrier of antioxidants for active films [37] or be favorable to cell adhesion [31]. High roughness could affect film strength and barrier properties [38], and a film optimization is necessary for specific applications.

\subsection{Clean Biopolymer}

The yields of clean biopolymers of No, Sy and Pp was 323, 204 and 83 mg/L, respectively. The biopolymer production depends on the type of microorganism, culture conditions, type of bioreactor, and techniques of biopolymer isolation and purification [39]. Yeast, bacteria, and fungi are the main microorganism used for biopolymer production due to high yields obtained such as 6320-7960 mg/L from Streptomyces carpaticus [40], 461-737 mg/L from Lactobacillus rhamnosus [41], and $600 \mathrm{mg} / \mathrm{L}$ from Aspergillus sp. Y16 [42]. These yields are higher than those obtained with microalgae. Nevertheless, those microorganisms permanently require an organic carbon source for their growth. Microalgae, on the opposite, are capable of assimilating inorganic sources of carbon such as carbon dioxide, helping in regulating this greenhouse gas and transforming it into high-value compounds. 
As mentioned above, the use of microalgae for producing high-value products and biopolymers is an environmentally friendly alternative; in order to increase the production yields of these products, it is necessary to continue with the selection for the best choice of strain and the optimization of culture conditions, such as light quality [43], light intensity, and nitrogen availability [44].

The FT-IR analysis was done using clean biopolymers. The infrared spectra of clean biopolymers from No, Pp, and Sy (Supplementary Figures S1-S3) showed absorption bands at 1260, 1255.5, and $1250 \mathrm{~cm}^{-1}$, respectively, attributed to stretching vibrations of sulfate ester groups. The absorption band was stronger for $\mathrm{Pp}$ than for No and Sy. Additionally, broadbands of $\mathrm{O}-\mathrm{H}$ stretching at 3435.6, 3400.3, and $3412.3 \mathrm{~cm}^{-1}$ were observed for No, Pp, and Sy respectively; an absorption band at $2930 \mathrm{~cm}^{-1}$ was obtained for the three biopolymers due to stretching vibrations of $\mathrm{C}-\mathrm{H}$, and absorption bands at 1640.6, 1638.9 , and $1655.7 \mathrm{~cm}^{-1}$ were in the same order, corresponding to stretching vibrations of $\mathrm{C}=\mathrm{O}$ from the carboxyl group, and bands at 1082.6, 1090.9 and, $1055.8 \mathrm{~cm}^{-1}$ corresponded to stretching vibrations of asymmetric and symmetric $\mathrm{C}-\mathrm{O}-\mathrm{C}$ bonds and alcoholic $\mathrm{C}-\mathrm{O}$ stretching vibrations, which indicated the presence of carboxylic acids [45] and carbohydrates [46].

\subsection{Antifungal Activity}

The antifungal activity test was done only with the No clean biopolymer, since this strain showed the best biopolymer yield after the clean-up process. Figure 4 shows the inhibition percentage against six fungal strains. The best growth inhibition was achieved against Fusarium verticillioides, a potential pathogen of maize [47], with the maximum inhibition rate of $70.2 \%$ at $96 \mathrm{~h}$. Helminthosporium sp. and Curvularia sp. did not display growth inhibition by the biopolymer.

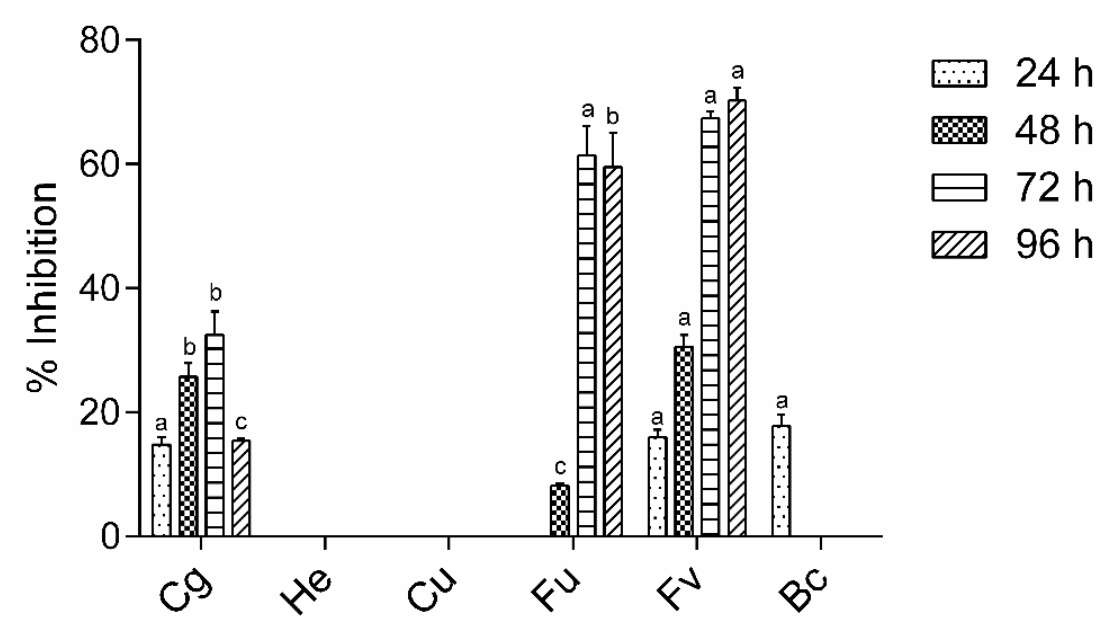

Figure 4. Antifungal inhibition (\%) of NO's clean biopolymer $(2.24 \mathrm{mg} / \mathrm{mL})$ against Colletotrichum. gloeosporioides $(\mathrm{Cg})$, Helminthosporium sp. (He); Curvularia sp. (Cu); Fusarium sp. (Fu); Fusarium. verticillioides $(\mathrm{Fv})$, and Botrytis. cinerea $(\mathrm{Bc})$. Data are shown as mean $\pm \mathrm{SE}(\mathrm{n}=2)$. Means with different letters are significantly different according to ANOVA and the Tukey test $(p<0.05)$. Comparisons between strains were performed for each time.

The studies done by Geresh et al. [48], concerning the biological activity of sulfated polysaccharides from marine microalgae Porphyridium sp. and Rhodella reticulate, revealed an inhibitory activity against neoplastic mammalian cell lines, and it was attributed to the negative charge of native sulfated and oversulfated exopolysaccharides and to the presence of glucuronic acid. Nevertheless, there are no data about the antifungal activities of the extracellular biopolymer microalgae of the strains reported in this study against the six phytopathogenic fungi. The present study shows that the No extracellular biopolymer could be an environmentally friendly alternative for fungi control amongst other already researched applications. 


\subsection{Antibacterial Activity}

Neither Escherichia coli or Xanthomonas campestris showed growth inhibition for the two concentrations of the No clean biopolymer used. The results obtained in the present study for Escherichia coli were similar to that discovered by Najdenski et al. [49], where they did not find an inhibitory effect in the exopolysaccharides of Nostoc entophytum and Nostoc muscorum.

\subsection{Antioxidant Activity}

The clean biopolymers from the microalgae No, Pp, and Sy did not present antioxidant capacity. This means that the biopolymer were not capable of removing the ABTS radical generated in the aqueous phase. Sun et al. [50] found that the extracellular biopolymer (polysaccharide) of Porphyridium cruentum showed a weak antioxidant activity using the DPPH method, which was due to its high molecular weight and insolubility. Nevertheless, they observed that the hermetical microwave radiation to the polymer coupled to column separation allowed obtaining low-molecular-weight fragments, which could scavenge the radical generated with higher intensity than that of the nondegraded biopolymer.

\subsection{Emulsification Capacity}

The emulsification index $\left(\mathrm{E}_{24}\right)$ results showed important differences between the crude extracellular medium and the cleaned one. Pp did not present emulsifying capacity in the crude extracellular medium, but in the clean one an $\mathrm{E}_{24}$ value of $73.3 \%$ was obtained (Figure 5). In the same way, the $\mathrm{E}_{24}$ value of No increased by $60.8 \%$, and that of Sy presented a small increase of $6.3 \%$. These results indicated that salts and compounds were eliminated during the cleaning process, avoiding the exposure of the hydrophilic part of the biopolymer, which permitted it to form the emulsion. The maximum emulsifying capacity was $77.5 \%, 73.3 \%$, and $68.8 \%$ for No, Pp, and Sy, respectively, with concentrations of the clean biopolymers of $0.323,0.083$, and $0.204 \mathrm{mg} / \mathrm{mL}$, respectively. The percentages found in this work are higher than the value of $59.1 \%$ found using surfactin $\left(\mathrm{C}_{14} / \mathrm{Lue}_{7}\right)$ produced by Bacillus subtillis with a concentration of $1.0 \mathrm{mg} / \mathrm{mL}$ and evaluated with kerosene [51]. It is also a higher value than the one found in the Arthrospira (Spirulina) platensis protein isolate, which was approximately $65 \%$ at $\mathrm{pH} 10$ with a concentration of $100 \mathrm{mg} / \mathrm{mL}$ and evaluated using sunflower oil [30].

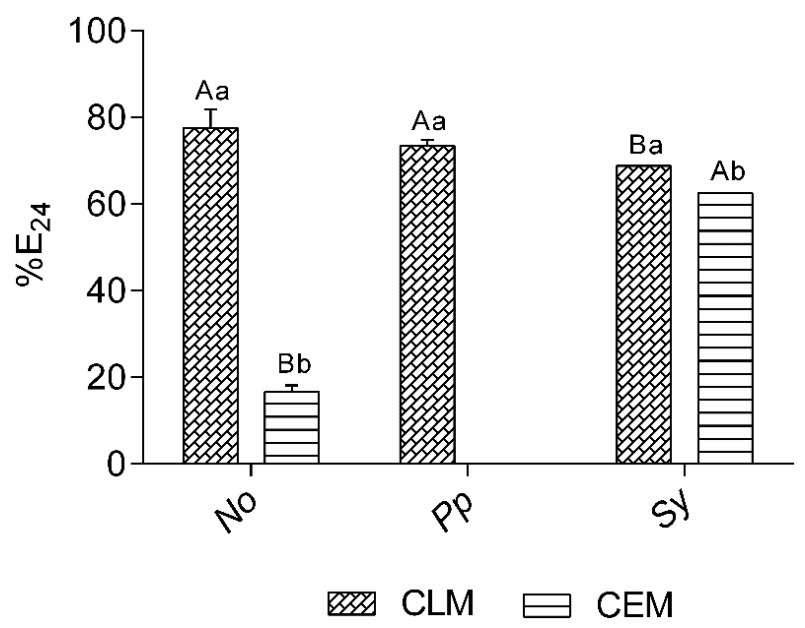

Figure 5. Emulsification index $\mathrm{E}_{24}$ (\%). CLM: clean extracellular medium. CEM: crude extracellular medium. No: Nostoc sp.; Pp: Porphyridium purpureum; Sy: Synechocystis sp. Data are shown as mean \pm SE $(n=3)$. Means with different letters are significantly different according to ANOVA and the Tukey test $(p<0.05)$. Capital letters are for comparisons between strains, and small letters are for comparisons between treatments. 
The microalgae biopolymer, as a biosurfactant or bioemulsifier, could play an important role in enhanced oil recovery [52] and the bioremediation of water or soil contaminated with hydrocarbon [53] and heavy metals. Moreover, the resulting biopolymer could find potential applications such as a nanoparticles stabilizer, an antimicrobial agent, and an additive in processed food, cosmetics, and textile industries [54].

\section{Conclusions}

The importance of using biopolymers and biofilms with functionality is crucial in the modern societies. From the six microalgae strain screening, the biopolymers from the spent culture media of $\mathrm{Py}, \mathrm{NO}$, and Sy were produced and isolated. All polymers had remarkable emulsification capacities, although they did not display antioxidant activity. Importantly, this study showed, for the first time, that the biopolymers of Pp and No had the capacity to form rough biofilms with pores and cracks. Herein, further research should be performed on preparing compelling biofilms.

It is worth highlighting the considerable antifungal activity of $\mathrm{No}^{\prime}$ extracellular biopolymer against Fusarium verticillioides, Fusarium sp. and small activities against Colletotrichum gloeosporioides and Botrytis cinerea. The results found in this work indicated that the microalgae biopolymer could be potentially useful in areas, such as food, feed, and cosmetic packaging, and additives in processed food, fungi control, and membrane materials, resulting in great development of food preservation and health-enhancing foods.

Supplementary Materials: The following are available online at http://www.mdpi.com/2079-6412/10/2/120/s1, Figure S1: IR spectrum of clean biopolymer of No sp.; Figure S2: IR spectrum of the clean biopolymer of Pp; Figure S3: IR spectrum of the clean biopolymer of Sy sp.

Author Contributions: Conceptualization, M.M.-J., L.G., J.Y.-F., and B.E.B.-H.; Writing of the original draft, M.M.-J., L.G., J.Y.-F., and B.E.B.-H.; writing of review and editing, M.M.-J., L.G., J.Y.-F., R.C.-M., and B.E.B.-H. All authors have read and agreed to the published version of the manuscript.

Funding: This research received no external funding.

Acknowledgments: The authors would like to acknowledge the projects: ALGAVALOR-MicroALGAs: produção integrada e VALORização da biomassa e das suas diversas aplicações, from the Portugal 2020 programme (grant agreement $n^{\circ}$ POĆI-01-0247-FEDER-035234; LISBOA-01-0247-FEDER-035234; ALG-01-0247-FEDER-035234); GreenCoLab-Green Ocean Technologies and Products Collaborative Laboratory, n. ${ }^{\circ}$ ALG-05-3559-FSE-000010, Algarve 2020 Operational Regional Program, funded by European Social Fund and Portuguese Government budget; Graça Gomes (LNEG) and Natércia Santos (LNEG) for microalgae culture maintenance and laboratory assistance. The authors gratefully acknowledge financial support by the Consejo Nacional de Ciencia y Tecnología (CONACYT) of Mexico through the scholarship to M.M.-J., with the support of the project SIP-20195891, from Instituto Politécnico Nacional.

Conflicts of Interest: The authors declare no conflicts of interest.

\section{References}

1. Tharanathan, R.N. Biodegradable films and composite coatings: Past, present and future. Trends Food Sci. Technol. 2003, 14, 71-78. [CrossRef]

2. Cerqueira, M.A.; Sousa-Gallagher, M.J.; Macedo, I.; Rodriguez-Aguilera, R.; Souza, B.W.S.; Teixeira, J.A.; Vicente, A.A. Use of galactomannan edible coating application and storage temperature for prolonging shelf-life of "Regional" cheese. J. Food Eng. 2010, 97, 87-94. [CrossRef]

3. Cerqueira, M.A.; Souza, B.W.S.; Martins, J.T.; Teixeira, J.A.; Vicente, A.A. Seed extracts of Gleditsia triacanthos: Functional properties evaluation and incorporation into galactomannan films. Food Res. Int. 2010, 43, 2031-2038. [CrossRef]

4. Lin, D.; Zhao, Y. Innovations in the development and application of edible coatings for fresh and minimally processed fruits and vegetables. Compr. Rev. Food Sci. Food Saf. 2007, 6, 60-75. [CrossRef]

5. Santacruz, S.; Rivadeneira, C.; Castro, M. Edible films based on starch and chitosan. Effect of starch source and concentration, plasticizer, surfactant's hydrophobic tail and mechanical treatment. Food Hydrocoll. 2015, 49, 89-94. [CrossRef] 
6. Pereira, J.; Simões, M.; Silva, J.L. Microalgal assimilation of vitamin B12 toward the production of a superfood. J. Food Biochem. 2019, 43, 1-15. [CrossRef]

7. Gouveia, L.; Marques, A.E.; Sousa, J.M.; Moura, P.; Bandarra, N.M. Microalgae-Source of natural bioactive molecules as functional ingredients. Food Sci. Technol. Bull. Funct. Foods 2010, 7, 21-37. [CrossRef]

8. Gouveia, L.; Coutinho, C.; Mendonça, E.; Batista, A.P.; Sousa, I.; Bandarra, N.M.; Raymundo, A. Functional biscuits with PUFA-w3 from Isochrysis galbana. J. Sci. Food Agric. 2008, 88, 891-896. [CrossRef]

9. Gouveia, L.; Batista, A.P.; Miranda, A.; Empis, J.; Raymundo, A. Chlorella vulgaris biomass used as colouring source in traditional butter cookies. Innov. Food Sci. Emerg. Technol. 2007, 8, 433-436. [CrossRef]

10. Gouveia, L.; Raymundo, A.; Batista, A.P.; Sousa, I.; Empis, J. Chlorella vulgaris and Haematococcus pluvialis biomass as colouring and antioxidant in food emulsions. Eur. Food Res. Technol. 2006, 222, 362-367. [CrossRef]

11. You, T.; Barnett, S.M. Effect of light quality on production of extracellular polysaccharides and growth rate of Porphyridium cruentum. Biochem. Eng. J. 2004, 19, 251-258. [CrossRef]

12. Vonshak, A. Microalgae: Laboratory growth techniques and the biotechnology of biomass production. In Photosynthesis and Production in a Changing Environment; Springer: Dordrecht, The Netherlands, 1993; pp. 337-355.

13. Stanier, R.Y.; Deruelles, J.; Rippka, R.; Herdman, M.; Waterbury, J.B. Generic assignments, strain histories and properties of pure cultures of cyanobacteria. Microbiology 1979, 111, 1-61.

14. Arzate-Vázquez, I.; Chanona-Pérez, J.J.; Calderón-Domínguez, G.; Terres-Rojas, E.; Garibay-Febles, V.; Martínez-Rivas, A.; Gutiérrez-López, G.F. Microstructural characterization of chitosan and alginate films by microscopy techniques and texture image analysis. Carbohydr. Polym. 2012, 87, 289-299. [CrossRef]

15. Sun, H.Y.; Wang, H.C.; Chen, Y.; Li, H.X.; Chen, C.J.; Zhou, M.G. Multiple resistance of Botrytis cinerea from vegetable crops to carbendazim, diethofencarb, procymidone, and pyrimethanil in China. Plant Dis. 2010, 94, 551-556. [CrossRef] [PubMed]

16. Sadat Ebrahimi, M.M.; Dohm, N.; Müller, M.; Jansen, B.; Schönherr, H. Self-reporting hydrogels rapidly differentiate among enterohemorrhagic Escherichia coli (EHEC) and non-virulent Escherichia coli (K12). Eur. Polym. J. 2016, 81, 257-265. [CrossRef]

17. Volkmer, B.; Heinemann, M. Condition-dependent cell volume and concentration of Escherichia coli to facilitate data conversion for systems biology modeling. PLoS ONE 2011, 6, 1-6. [CrossRef]

18. Re, R.; Pellegrini, N.; Proteggente, A.; Pannala, A.; Yang, M.; Rice-Evans, C. Antioxidant activity applying an improved ABTS radical cation decolorization assay. Free Radic. Biol. Med. 1999, 26, 1231-1237. [CrossRef]

19. Techaoei, S.; Lumyong, S.; Prathumpai, W.; Santiarwar, D.; Leelapornp, P. Screening characterization and stability of biosurfactant produced by Pseudomonas aeruginosa SCMU106 isolated from soil in northern Thailand. Asian J. Biol. Sci. 2011, 4, 340-351. [CrossRef]

20. Lowry, O.H.; Rosebrough, N.J.; Farr, A.L.; Randall, R.J. Protein measurement with the Folin phenol reagent. J. Biol. Chem. 1951, 193, 265-275.

21. DuBois, M.; Gilles, K.A.; Hamilton, J.K.; Rebers, P.A.; Smith, F. Colorimetric method for determination of sugars and related substances. Anal. Chem. 1956, 28, 350-356. [CrossRef]

22. Barrocal, V.M.; García-Cubero, M.T.; González-Benito, G.; Coca, M. Production of biomass by Spirulina maxima using sugar beet vinasse in growth media. N. Biotechnol. 2010, 27, 851-856. [CrossRef]

23. Joana Gil-Chávez, G.; Villa, J.A.; Fernando Ayala-Zavala, J.; Basilio Heredia, J.; Sepulveda, D.; Yahia, E.M.; González-Aguilar, G.A. Technologies for extraction and production of bioactive compounds to be used as nutraceuticals and food ingredients: An overview. Compr. Rev. Food Sci. Food Saf. 2013, 12, 5-23. [CrossRef]

24. Ciapponi, R.; Turri, S.; Levi, M. Mechanical reinforcement by microalgal biofiller in novel thermoplastic biocompounds from plasticized gluten. Materials 2019, 12, 1476. [CrossRef]

25. Carissimi, M.; Flôres, S.H.; Rech, R. Effect of microalgae addition on active biodegradable starch film. Algal Res. 2018, 32, 201-209. [CrossRef]

26. Fabra, M.J.; Martínez-Sanz, M.; Gómez-Mascaraque, L.G.; Gavara, R.; López-Rubio, A. Structural and physicochemical characterization of thermoplastic corn starch films containing microalgae. Carbohydr. Polym. 2018, 186, 184-191. [CrossRef]

27. Khan, S.; Siddique, R.; Sajjad, W.; Nabi, G.; Hayat, K.M.; Duan, P.; Yao, L. Biodiesel production from algae to overcome the energy crisis. HAYATI J. Biosci. 2017, 24, 163-167. [CrossRef] 
28. Gloaguen, V.; Ruiz, G.; Morvan, H.; Mouradi-Givernaud, A.; Maes, E.; Krausz, P.; Strecker, G. The extracellular polysaccharide of Porphyridium sp.: An NMR study of lithium-resistant oligosaccharidic fragments. Carbohydr. Res. 2004, 339, 97-103. [CrossRef]

29. Andhare, P.; Goswami, D.; Delattre, C.; Pierre, G.; Michaud, P.; Pathak, H. Edifying the strategy for the finest extraction of succinoglycan from Rhizobium radiobacter strain CAS. Appl. Biol. Chem. 2017, 60, 339-348. [CrossRef]

30. Benelhadj, S.; Gharsallaoui, A.; Degraeve, P.; Attia, H.; Ghorbel, D. Effect of pH on the functional properties of Arthrospira (Spirulina) platensis protein isolate. Food Chem. 2016, 194, 1056-1063. [CrossRef]

31. Bueno, C.Z.; Dias, A.M.A.; De Sousa, H.J.C.; Braga, M.E.M.; Moraes, Â.M. Control of the properties of porous chitosan-alginate membranes through the addition of different proportions of Pluronic F68. Mater. Sci. Eng. C 2014, 44, 117-125. [CrossRef]

32. Demirci, F.; Yildirim, K.; Kocer, H.B. Antimicrobial open-cell polyurethane foams with quaternary ammonium salts. J. Appl. Polym. Sci. 2018, 135, 16-20. [CrossRef]

33. Bierhalz, A.C.K.; Westin, C.B.; Moraes, Â.M. Comparison of the properties of membranes produced with alginate and chitosan from mushroom and from shrimp. Int. J. Biol. Macromol. 2016, 91, 496-504. [CrossRef]

34. Castro-Muñoz, R.; González-Valdez, J. New trends in biopolymer-based membranes for pervaporation. Molecules 2019, 24, 3584. [CrossRef]

35. Galiano, F.; Briceño, K.; Marino, T.; Molino, A.; Christensen, K.V.; Figoli, A. Advances in biopolymer-based membrane preparation and applications. J. Memb. Sci. 2018, 564, 562-586. [CrossRef]

36. Chalermthai, B.; Chan, W.Y.; Bastidas-Oyanedel, J.R.; Taher, H.; Olsen, B.D.; Schmidt, J.E. Preparation and characterization of whey protein-based polymers produced from residual dairy streams. Polymers 2019, 11, 722. [CrossRef]

37. Ganiari, S.; Choulitoudi, E.; Oreopoulou, V. Edible and active films and coatings as carriers of natural antioxidants for lipid food. Trends Food Sci. Technol. 2017, 68, 70-82. [CrossRef]

38. Ghanbarzadeh, B.; Oromiehi, A.R. Biodegradable biocomposite films based on whey protein and zein: Barrier, mechanical properties and AFM analysis. Int. J. Biol. Macromol. 2008, 43, 209-215. [CrossRef]

39. Freitas, F.; Torres, C.A.V.; Reis, M.A.M. Engineering aspects of microbial exopolysaccharide production. Bioresour. Technol. 2017, 245, 1674-1683. [CrossRef]

40. Selim, M.S.; Amer, S.K.; Mohamed, S.S.; Mounier, M.M.; Rifaat, H.M. Production and characterisation of exopolysaccharide from Streptomyces carpaticus isolated from marine sediments in Egypt and its effect on breast and colon cell lines. J. Genet. Eng. Biotechnol. 2018, 16, 23-28. [CrossRef]

41. Riaz Rajoka, M.S.; Jin, M.; Haobin, Z.; Li, Q.; Shao, D.; Jiang, C.; Huang, Q.; Yang, H.; Shi, J.; Hussain, N. Functional characterization and biotechnological potential of exopolysaccharide produced by Lactobacillus rhamnosus strains isolated from human breast milk. LWT Food Sci. Technol. 2018, 89, 638-647. [CrossRef]

42. Chen, Y.; Mao, W.; Tao, H.; Zhu, W.; Qi, X.; Chen, Y.; Li, H.; Zhao, C.; Yang, Y.; Hou, Y.; et al. Structural characterization and antioxidant properties of an exopolysaccharide produced by the mangrove endophytic fungus Aspergillus sp. Y16. Bioresour. Technol. 2011, 102, 8179-8184. [CrossRef]

43. Han, P.P.; Shen, S.G.; Wang, H.Y.; Sun, Y.; Dai, Y.J.; Jia, S.R. Comparative metabolomic analysis of the effects of light quality on polysaccharide production of cyanobacterium Nostoc flagelliforme. Algal Res. 2015, 9, 143-150. [CrossRef]

44. Otero, A.; Vincenzini, M. Extracellular polysaccharide synthesis by Nostoc strains as affected by N source and light intensity. J. Biotechnol. 2003, 102, 143-152. [CrossRef]

45. Grünewald, N.; Alban, S. Optimized and standardized isolation and structural characterization of anti-inflammatory sulfated polysaccharides from the red alga Delesseria sanguinea (Hudson) Lamouroux (Ceramiales, Delesseriaceae). Biomacromolecules 2009, 10, 2998-3008. [CrossRef]

46. Anvari, M.; Tabarsa, M.; Cao, R.; You, S.; Joyner Melito, H.S.; Behnam, S.; Rezaei, M. Compositional characterization and rheological properties of an anionic gum from Alyssum homolocarpum seeds. Food Hydrocoll. 2016, 52, 766-773. [CrossRef]

47. Blacutt, A.A.; Gold, S.E.; Voss, K.A.; Gao, M.; Glenn, A.E. Fusarium verticillioides: Advancements in understanding the toxicity, virulence, and niche adaptations of a model mycotoxigenic pathogen of maize. Phytopathology 2018, 108, 312-326. [CrossRef]

48. Geresh, S.; Mamontov, A.; Weinstein, J. Sulfation of extracellular polysaccharides of red microalgae: Preparation, characterization and properties. J. Biochem. Biophys. Methods 2002, 50, 179-187. [CrossRef] 
49. Najdenski, H.M.; Gigova, L.G.; Iliev, I.I.; Pilarski, P.S.; Lukavský, J.; Tsvetkova, I.V.; Ninova, M.S.; Kussovski, V.K. Antibacterial and antifungal activities of selected microalgae and cyanobacteria. Int. J. Food Sci. Technol. 2013, 48, 1533-1540. [CrossRef]

50. Sun, L.; Wang, C.; Shi, Q.; Ma, C. Preparation of different molecular weight polysaccharides from Porphyridium cruentum and their antioxidant activities. Int. J. Biol. Macromol. 2009, 45, 42-47. [CrossRef]

51. De Faria, A.F.; Teodoro-Martinez, D.S.; De Oliveira Barbosa, G.N.; Gontijo Vaz, B.; Serrano Silva, Í.; Garcia, J.S.; Tótola, M.R.; Eberlin, M.N.; Grossman, M.; Alves, O.L.; et al. Production and structural characterization of surfactin (C 14/Leu7) produced by Bacillus subtilis isolate LSFM-05 grown on raw glycerol from the biodiesel industry. Process Biochem. 2011, 46, 1951-1957. [CrossRef]

52. Geetha, S.J.; Banat, I.M.; Joshi, S.J. Biosurfactants: Production and potential applications in microbial enhanced oil recovery (MEOR). Biocatal. Agric. Biotechnol. 2018, 14, $23-32$.

53. Souza, E.C.; Vessoni-Penna, T.C.; De Souza Oliveira, R.P. Biosurfactant-enhanced hydrocarbon bioremediation: An overview. Int. Biodeterior. Biodegrad. 2014, 89, 88-94. [CrossRef]

54. Santos, D.K.F.; Rufino, R.D.; Luna, J.M.; Santos, V.A.; Sarubbo, L.A. Biosurfactants: Multifunctional biomolecules of the 21st century. Int. J. Mol. Sci. 2016, 17, 401. [CrossRef] [PubMed]

(C) 2020 by the authors. Licensee MDPI, Basel, Switzerland. This article is an open access article distributed under the terms and conditions of the Creative Commons Attribution (CC BY) license (http://creativecommons.org/licenses/by/4.0/). 